\title{
The Stories We Tell about Refugee Claimants: Contested Frames of the Health-Care Access Question in Canada
}

\author{
JESSE BEATSON ${ }^{1}$
}

\section{Abstract}

A contested issue is the extent to which refugee claimants should have access to health care in Western host countries with publicly subsidized health-care systems. In Canada, for a period of over fifty years, the federal government provided relatively comprehensive health coverage to refugees and refugee claimants through the Interim Federal Health Plan (IFHP). Significant cuts to the IFHP were implemented in June 2012 by the Conservative federal government (2006-15), who justified these cuts through public statements portraying refugee claimants as bringing bogus claims that inundate the refugee determination system. A markedly different narrative was articulated by a pan-Canadian coalition of health providers who characterized refugee claimants as innocent victims done further harm by inhumane health-care cuts. This article presents an analysis of these two positions in terms of frame theory, with a greater emphasis on the health-provider position. This debate can be meaningfully analyzed as a contest between competing frames: bogus and victim. Frame theory suggests that frames by nature simplify and condense, in this case packaging complex realities about refugee claimants into singular images (bogus and victim), aiming to inspire suspicion and compassion respectively. It will be argued that the acceptance of current frames impoverishes the conversation by reinforcing problematic notions about refugee claimants while also obscuring a rights-based argument for why claimants should have substantial access to health care.

\section{Résumé}

L'étendue de l'accès aux services de santé pour les demandeurs du statut de réfugié dans le contexte des pays d'accueil occidentaux munis de régimes de santé financés publiquement constitue un enjeu controversé. Au Canada, pendant plus de 50 ans, c'était le gouvernement fédéral qui fournissait une couverture relativement intégrale de services de santé aux réfugiés ainsi qu'aux demandeurs du statut de réfugié par l'entremise du Programme fédéral de santé intérimaire (PFSI). Des réductions importantes au PFSI ont été effectuées en juin 2012 par le gouvernement fédéral conservateur (2006-15), qui a justifié ces réductions par des déclarations publiques accusant les demandeurs du statut de réfugié d'avoir encombré le système de détermination $d u$ statut en présentant des demandes non légitimes. Un récit nettement différent avait été articulé par un regroupement pancanadien de fournisseurs de services de santé qui représentaient les demandeurs du statut de réfugié comme des victimes innocentes dont les réductions inhumaines aux services de soins de santé n'avaient fait qu'aggraver leur situation. Cet article présente une analyse de ces deux positions par l'entremise de la théorie de l'encadrement, en mettant l'accent particulièrement sur la position des fournisseurs de services de santé. Selon la thèse proposée par l'article, il serait profitable d'analyser les arguments émis dans ce débat en tant qu'affrontement entre deux cadres en concurrence, notamment le cadre de la non-légitimité et celui de la victimisation. La théorie de l'encadrement propose que les cadres, de par leur nature, simplifient et 
condensent le sujet dont il est question, dans ce cas les réalités complexes autour des demandeurs du statut de réfugié, en les réduisant à des images uniformes (non-légitimité et victime), avec le but d'inspirer soit la méfiance ou la compassion, respectivement. Le fait d'accepter ces cadres tels qu'ils sont présentés actuellement appauvrit le discours en renforçant des notions problématiques concernant les demandeurs du statut de réfugié, tout en refoulant des arguments fondés sur les droits qui favorisent un accès intégral aux services de santé pour les demandeurs.

\section{Introduction}

A central question for any publicly subsidized healthA care system is the extent to which non-citizens 1 should be granted access. Refugee claimants, by definition, are not yet citizens of the host state, and a continued debate is over what legitimate claims they have on social resources like health-care vis-à-vis citizens. Many scholars assert that refugee claimants should at the very least have access to emergency medical care, what Gibney argues is part of a "moral minimum" owed to precarious migrants. ${ }^{2}$ Beyond this baseline of care, opinions vary widely about whether any additional health-care benefits should be provided and under what conditions.

In Canada, the question of to what extent refugees and refugee claimants should have access to health care was contested in a heated and public manner, in the wake of cuts to the Interim Federal Health Program (IFHP). For over fifty years the Canadian government provided relatively comprehensive health insurance coverage to refugees and refugee claimants through the IFHP. When the Conservative federal government (February 2006-November 2015) significantly reduced the scope of this health coverage on 30 June 2012, all refugee claimants lost coverage of medications, and many others lost access to medical services, except for rare instances where health conditions were deemed a risk to public health or safety. ${ }^{3}$ On 19 October 2015, the Liberal Party was elected and in April 2016 restored IFHP health coverage to previous levels.

The scope of this article concerns the status of the IFHP under the Conservative government. It was this era in which the IFHP cuts were made, and accordingly, this is when the event of interest for this study took place: a discursive struggle in the media between the Conservative federal government and refugee health-provider advocates. For each of these two parties, their public statements can arguably be distilled into single generalizing labels applied to refugee claimants. These labels centred drastically different features that claimants allegedly exhibit.
This article demonstrates that these labels acted as shorthands for the more complex political positions of the Conservative federal government and doctor advocates, who were each endeavouring to steer a national conversation about what Canada owes to claimants in health coverage. This period of recent Canadian history (2012-16) presents an opportunity, therefore, to study how conflicting ways of representing refugee claimants in the media are linked to differing determinations about their entitlements to health services. In other words, it is a comparison between two different "stories" that have consequences. The consequences of these media portrayals are significant. We see in the United States the way that the portrayal of the "deserving" vs. "undeserving" poor has justified cuts in the social safety net. ${ }^{4}$ To this end, this article borrows conceptually and methodologically from frame theory, a type of discourse analysis. 5

The literature on frame theory is rich and diverse, with intellectual roots stretching back to the 1970s. ${ }^{6}$ The frame theory that is relevant here, however, is its recent application to the collective arena, exploring how frames are used strategically to mobilize people around particular political causes and issues. Attention will be paid to the inability of refugee claimants themselves to have participated as equal partners in the national conversation on their access to health care; the responsibilities that should flow from the fact of refugee claimants' muted political voice to those who speak on their behalf; the main frames that were in play regarding refugee claimant health care and what they highlighted, compared to what they obscured from view; and finally, the tension between the need for frames in an adversarial public dialogue and how even "pro-refugee" framing may have negative ramifications for the claimants who are being characterized.

\section{Background}

It is no wonder that refugee claimants are the subject of discursive activity. While the determination of their legal identities follows the relatively fixed process of immigration and refugee boards, their social identities are in limbo because they are between states of civic belonging; they have fled their country of origin and are not yet members of their host country. Lacking the benefits of citizenship in the host country, their political voices are muted. Simply put, they are not in a favourable position to have their own narratives and perspectives heard. Instead, they are an ideal screen upon which various images, conjured by more powerful and civically entrenched actors, can be projected. As noted by Phillips and Hardy, there are two components of refugee identity: first, what a refugee is; and second, who is 
and who is not a refugee. ${ }^{7}$ While the second component is determined largely by the legal and institutional processes of refugee determination, the first is a more open question, influenced largely by the discursive productions of actors who vie to advance their agendas.

Since refugee claimants have limits placed upon their capacity to, as it were, tell their own stories, a lot of power is placed in the hands of those who do this representational work on their behalf. Malkki notes that even when discourses on refugees or refugee claimants attempt to empower and humanize, they inevitably construct a limiting "vision of humanity that repels elements that fail to fit into the logic of its framework." In other words, discursive constructions of refugees necessarily entail generalizations that deny complexity and the uniqueness of the individual. To advance a side of a public debate, even if it is a "prorefugee" stance, generalizations will be necessary. Nonetheless, the degree to which the potential harm of these generalizations is outweighed by benefits is an area for critical inquiry and assessment.

A tension presents itself to those who would put themselves in the role of advocates. On the one hand, there is a responsibility to do justice to the complexities of what is essentially other people's lives, to render into high resolution their diverse experiences and subjectivities. On the other hand, there is a practical necessity to put forward an advocacy message that is clear and concise enough for it to be effectively digestible and able to circulate widely. The concept of a frame is a helpful analytic device for understanding the discursive process that occurs in substituting relatively clean-lined images for necessarily jagged realities. Importantly, frames do not fit the world as it is, and by extension, they are never neutral representations. 9 The subject of a frame is like the elephant from a famous parable. The frames themselves are the blind men who each appraise one facet of the animal: upon comparing notes, they are inevitably going to disagree about what they are describing because each has only one piece of the puzzle.

Frame theory has a rich academic lineage, dating back to the mid-1970s. Goffman, a sociologist, studied institutions and contended that every institution is structured by a frame, a kind of unconscious social script. Goffman defined a frame as a "schemata of interpretation" that enables individuals "to locate, perceive, identify, and label" events and phenomena occurring in the world. ${ }^{10}$ Fillmore, a linguist, wrote about frames at around the same time and proposed that every word is defined with respect to a frame. As an example, the word surgeon has a series of readily triggered linguistic and conceptual associations, such as operating room and scalpel, which in turn enrich our understanding of the original word. ${ }^{11}$ In both Goffman's and Fillmore's accounts, frames are structures that inform, as well as constrain, the way a thing is talked about and understood. More recently, the concept of frames has been employed in the collective arena, with frame analysis studying how frames might be strategically used in social mobilization. KliglerVilenchik and Thorson note that participants and observers in a public discourse may not be able to name the "title" or "category" of a frame. ${ }^{12}$ They may still have a sense for how the ideas in a frame cluster together, what have been called "interpretative packages."13

Once seen through the angle of vision provided by a certain frame, its subject can become difficult to perceive and interpret in alternative ways. Indeed, when unchallenged, a frame can become what Bourdieu termed doxa, an established way of thinking about something that is presented as self-evident and experienced as the "natural world that is taken for granted."14 This persistence of frames to shape thinking has been studied by cognitive linguists such as Lakoff, who posit that frames are not simply abstract entities but have corresponding physical manifestation in neural structures in the brain. ${ }^{15}$

Frames are not equivalent to ideologies, though there are surface similarities. Ideology is defined by Benford and Snow as "pervasive and integrated sets of beliefs and values" that have historical longevity. ${ }^{16}$ Frames, by contrast, can be employed as extensions of, or correctives to, existing ideologies. Accordingly, ideology can either constrain or bolster framing processes. ${ }^{17}$ Benford and Snow call this "meaning work - the struggle over the production of mobilizing and countermobilizing ideas and meanings," ${ }^{18}$ while Hall terms it "the politics of signification."19 I will use the term frame contest. Underlying these concepts is the notion that meaning is constructed in a dynamic and evolving process, an ongoing contest of frames and counter-frames. Having a convincing frame or frames will give one a greater chance of shaping how an issue in question is viewed.

\section{Methods}

Teo describes how discourse analysis is particularly wellsuited for examining data such as news articles and press releases containing messages that seem, or are portrayed as, neutral but that nonetheless contain ideological content. ${ }^{20}$ Academic journal articles, newspaper articles, and press releases published between April 2012 and November 2015 were examined. Given the primary interest of this article on responses to the IFHP cuts, an initial search was performed on PubMed and Medline with the keyword phrase Canada cuts to refugee health, with each database yielding 9 results. A similar search was repeated using Google Scholar with a custom range of 2012-15 and with the added exact phrase refugee health, yielding 339 results. A Google News search 
was performed further targeting articles tagged with Canadian doctors for refugee care, yielding 91 results. In addition, the CDRC website was consulted, particularly the sections titled "Further reading/survey" - a collection of CDRC press releases-and "In the news"-a list of newspaper articles related to refugee health advocacy in Canada. All articles related to the IFHP cuts were retrieved and considered for analysis. A subsequent search on Google Scholar used the phrases refugee bogus, refugee victim, refugee rights, and refugee right to health.

Analysis followed an iterative, inductive process, as is standard in discourse analytic methods. While reading through the sources, text sequences that characterized and defined refugee claimants, whether positively or negatively, were collected. Thematic recurrences of subject matter were recorded until the predominant character of both Conservative federal government discourse and CDRC discourse emerged. The structural features of these "texts" were not analyzed, as the focus was not on macro-level analysis but instead on identifying primary discourses through the collection of relevant and frequently appearing text sequences. This process allowed for a preliminary mapping out of frames in discourse in relation to the contested issue of refugee health-care coverage.

The government discourse was found to centre on notions of bogus refugees threatening limited health-care resources, while CDRC discourse most often advanced an image of refugee claimants as victims deserving care and consideration. Codes for these bogus and victim frames were then applied manually to sources to isolate and retrieve relevant text sequences for further analysis. This study was exempt from ethics review.

\section{Conservative Party of Canada: The Bogus Frame}

The Conservative federal government defended cuts to the IFHP by implying that these measures would protect the immigration system from refugee claimants who are allegedly "bogus" and intent on taking advantage of Canadian generosity. This phrase bogus refugee has been a particularly charged and oft-recurring theme in Conservative Party discourse. ${ }^{21}$ In a discourse analysis of Canadian media, Bauder found that the term bogus refugee appeared most frequently in the weeks before immigration legislation was tabled, suggesting a link between discourse and efforts towards legislative change. ${ }^{22}$ Negative rhetoric such as this is mirrored in the popular media and political discourse of other Western countries, where language is often dehumanizing and likens refugees and refugee claimants to swarms of insects or catastrophic floods, signifiers of threat to host societies. ${ }^{23}$

Characterizing refugee claimants as bogus, Conservative Party discourse suggested that claimants are in some sense fraudulent outsiders whose health status is beyond the pale of communal concern. Jason Kenney, former Conservative Party immigration minister, articulated the cuts to refugee health-care as a measure taken to ensure that "tax dollars are spent wisely" and to "defend the integrity of [the] immigration system" from "bogus claimants." ${ }^{24}$ According to Kenney, there is "no legal, moral, or political obligation to give taxpayer services to bogus asylum-seekers, rejected claimants-people who are effectively illegal migrants."25

With the bogus frame portraying refugee claimants as opportunistic "queue-jumpers" who do not deserve "goldplated health-care," a sweeping portrait of suspicion was created. ${ }^{26}$ This framing was applied "at every moment from the time when [claimants] decide to depart to the moment when they present themselves for determination."27 Although Canadians tend to be generally pro-immigration, they are often more reticent regarding refugee claimants. As Tribe has observed, "Refugees are often resented by the host nation, which may feel less than inclined to put resources into refugee health and they may be attributed marginal or 'out-group' status." 28 Negative attitudes toward refugee claimants were more prevalent following the August 2010 arrival of nearly 500 Tamil refugee claimants on the Mv Sun Sea, portrayed by the Conservative government as potential terrorists as well as "queue-jumpers." 29 In a winter 2010 poll, 70 per cent of Canadians indicated that they had doubts about the validity of many refugee claims..$^{30}$ More recently, a poll from the Angus Reid Institute found that two in five Canadians wanted Canada to immediately stop taking Syrian refugees..$^{31}$

The stated rationale for the IFHP cuts is misleading, both in its characterization of refugee claimants as bogus and in its suggestion that only these allegedly bogus claimants were affected by IFHP cuts. The notion of bogus refugee claimants elides the fact that many claimants eventually become Canadian citizens and hence cannot possibly have anything but legitimate claims. Canada's own Immigration and Refugee Boards found that half of the 19,960 claims processed in 2014 met the strict criteria for refugee determination-this includes many claims made from so-called designated countries of origin (DCO), countries like Mexico and Hungary that Conservative government policy categorized as "safe" and thus not refugee-producing. ${ }^{22}$

As noted in a press release by the Canadian Association of Refugee Lawyers (CARL), the refugee definition is technical, and even for those who do not meet these strict criteria it does not necessarily indicate any malicious intentions: "Many claimants come with a genuine fear of harm but may not meet the definition of a refugee. That does not make them frauds or bogus, or abusers of the system. Their search for protection is genuine." 33 In terms of the suggestion that 
only so-called bogus refugees were targeted by the cuts, the federal government's own "Summary of Benefits" webpage stated that cuts affected all refugee claimants while their claims were being processed, not only once their applications have been rejected. ${ }^{34}$

\section{Canadian Doctors for Refugee Care: The Victim Frame}

In response to refugee health cuts, a pan-Canadian coalition of health professionals formed called Canadian Doctors for Refugee Care. CDRC advocated for the restoration of IFHP health coverage to prior levels. CDRC and its individual members worked both behind the scenes-enlisting health professional associations and lobbying with political parties-and in public, including occupying the offices of members of Parliament, publically confronting Conservative MPs, and organizing public rallies. ${ }^{35}$ Furthermore, along with two other public interest applicants-CARL and the Toronto legal clinic Justice for Children and Youth-CDRC engaged in a legal challenge of IFHP cuts. CDRC's legal application to strike down the IFHP cuts of June 2012 was granted by a Federal Court in July 2014 on the grounds that the health cuts constituted "cruel and unusual treatment." 36

The aim of much of CDRC's advocacy work seemed to focus on replacing negative, widely circulated notions about refugee claimants with more positive, sympathetic representations. CDRC suggested that the term bogus "implies these are people who have made a fraudulent claim," which contradicts the reality that many have already been accepted and many others will be found to have legitimate claims." 37 Contrasting with the Conservative Party's representation of refugee claimants as bogus, CDRC highlighted the vulnerability of claimants in their public statements. Primarily, CDRC focused on an image of claimants as innocent victims. As victims, claimants were justified to be deserving recipients of publicly funded services. Moreover, CDRC placed a strong rhetorical emphasis on depicting Canadians as generous and compassionate. In a 23 October 2012 press release, for instance, CDRC suggested, "Our compassionate instincts as Canadians and the evidence points to the IFHP cuts being bad policy." 38 Hence, CDRC contended that that the health cuts were wrong both because they contradicted empirical evidence and because they violated the humanitarian values of Canadians.

According to CDRC, "The impact of the federal Conservative government's cuts has been devastating," for instance with many pregnant women, sick children, and cancer patients who experienced "unwarranted suffering" until the Federal Court reversed the cuts. ${ }^{39}$ Indeed, CDRC described refugee claimants in Canada as "some of the most vulnerable people in the world" and "the most insecure and defenseless among us," often experiencing "poor mental health" and might be "suicidal or suffering from posttraumatic stress disorder." 40

CDRC argued that the Conservative government's framing of restricting refugee health care as a public safety issue dehumanized refugee claimants: "The refugee person in this context is no longer valuable as a unique and worthy human being but is considered a 'risk factor' for others." 41 Here CDRC challenged Conservative Party discourse that borrowed the language of public health and contributed to negative and dehumanizing representations of refugee claimants. A CDRC press release of 27 January 2014 states, "This is not the fair and generous Canada that we know."42

In highlighting the vulnerability and victimhood of refugees and the compassion of Canadian citizens, this approach of CDRC's can be labelled a victim frame. Van Gorp studied Belgian media sources and demonstrated how coverage described refugee claimants in simplistic binaries as either "innocent victims" or as "intruders." 43 The victim frame was found to be associated with calls for and support of humanitarian policies. The intruder frame, on the other hand, was linked to anti-refugee policy proposals and sentiments. 44

\section{Risks in Employing a Victim Frame to Promote Health-Care Access}

While undeniably successful in many respects, CDRC's advocacy still warrants critical examination. Given a context where certain anti-refugee and anti-migrant discourses are widespread, the characteristics of refugee claimants that are highlighted in constructing more positive representations is a consequential topic worth analyzing. As a group, refugee claimants are often marginalized from mainstream services, and this is linked partly to discourse portraying them as "undeserving" in contrast to "deserving" refugees. 45 The counter-discourse to this binary separation of undeserving from deserving has tended to be couched in a humanitarian ethos. If refugee claimants are pictured uniformly as victims, as they were by CDRC, then it follows that they are all equally deserving.

Kurasawa highlights how an essential part of any humanitarian discourse is to "actively construct objects and sites for intervention" by naming vulnerable and victimized populations. ${ }^{46}$ Although assignment of victim status to refugee claimants may have some grounding in clinical realities, it is also connected to a particular framework-what Gottlieb, Filc, and Davidovitch call "medical humanitarianism"-that is not neutral in its assumptions about how best to allocate social resources and on what grounds. 47 Specifically, this framework is grounded in notions of charity, that the needy are broadly deserving of care. As this is a particular 
framework, rationalizing the granting of health care to claimants in a way that is not necessarily subscribed to by others who advocate for these same general goals, it will have its own consequences: positive and negative, intended or otherwise.

In assigning victim status to refugee claimants, a link was drawn to other characteristics of "ideal victims," such as passivity, weakness, helplessness, and neediness. ${ }^{48}$ If an individual in question does not fully embody those characteristics, there can be negative consequences; for example, the individual can lose tenuous, socially granted legitimacy and deservingness. One reason for losing this provisional legitimacy, as highlighted by Beiser, is through not repaying a debt of gratitude that some members of a host society may think is owed for the "generosity" refugees and refugee claimants have received. 49 This implicit requirement to repay such a social debt may put significant pressure on claimants and, moreover, may constrain their capacity to assert their rights or contest the conditions of their treatment.

Hardy and Phillips have argued that portraying refugee claimants as victims risks being overly paternalistic and "promotes a stereotypical view of refugees as helpless, defenceless individuals." 50 Moreover, suggesting that claimants as an entire population are victims can be seen as a form of Othering. Conceptualized by Said in his foundational text Orientalism, Othering involves a form of symbolic violence, the forcible creation of identities to fit a certain narrative. ${ }^{51}$ Contemporary scholarship by Johnson found that the image most frequently reproduced in photographs of refugee claimants is of individuals who are victimized and racialized..$^{2}$ Such images are so common that the subtle Othering contained in them might not be readily perceptible. Similarly, Rajaram raises concerns about images and discourses that reduce refugee claimants to their suffering bodies: "Corporeal, refugees are speechless and consigned to 'visuality': to the pictorial representation of suffering and need." 53 This emphasis on visual depictions of suffering may promote perceptions that refugee claimants are somehow more bodily beings than the host population, lacking in complex consciousness and the capacity for articulating nuanced opinions.

\section{Humanitarianism vs. Human Rights}

A victim frame as applied to health-care access for refugee claimants promotes a certain connection of health coverage as a type of humanitarian assistance. A clear hierarchy differentiates the generous giver from the recipient of charitable support. In contrast with rights discourses, humanitarian logic is "about the exception rather than the rule" and therefore is contrary to an advocacy position promoting the notion of universal rights. ${ }^{54}$ Arguments grounded in this status of the exceptional victim are "situationally specific and are about moral worthiness," which are contrasted with "universalizing juridical arguments" that apply across all contexts and are about formal entitlements to health rights. ${ }^{5}$ Although health advocacy informed by a humanitarian ethos share some "common ends" with rights-based advocacy, as noted by Slim, ${ }^{56}$ the difference in the underlying logic-charity versus obligation-has significant implications. 57 Whether or not refugee claimants "deserve" health coverage would be a largely irrelevant question from a perspective informed by rights.

In contrast to a hierarchical advocate-victim relation set up by humanitarian discourse, in rights-grounded advocacy marginalized individuals can theoretically become empowered by becoming their own advocates. This was proven to work to an extent in South Africa, where a campaign for access to medicines for the HIV-infected started in the 1990s and reached its height in the early 20oos. This campaign involved impoverished and infected individuals mobilizing and deploying a legal framework in making their demands. ${ }^{5}$ By contrast, advocacy based strictly on humanitarian principles leaves little room for the marginalized to participate as anything other than figures emblematic of victimization.

Within CDRC, there was a strong belief that refugees and refugee claimants have a right to health care.59 The decision to frame the issue around victimhood and deservingness is likely based, then, on an assessment that this is the most efficient strategy to garner broad support across the political and ideological spectrum. There are other pragmatic reasons perhaps that informed why CDRC did not lead with a rights discourse. Specifically, the victim frame avoids the potentially controversial and polarizing stance of attempting to elevate the status of refugee claimants in Canadian society on a more fundamental and permanent level, an agenda that may not have had enough public buy-in.

\section{Rights-Based Arguments: Challenges and Opportunities}

CDRC's adoption of a victim frame is not a neutral advocacy stance, and it is important to note that despite the prevalence of this frame in popular media, other alternatives are available. Given that there are several potential problems with the victim frame as a mode of advocacy, why then, as Taylor asks, are rights-based arguments used so infrequently in public discourse about refugee and refugee claimant issues?"0 Rights are the "banner under which struggles against oppression and exclusion have been fought (and sometimes won) over the past century," and "assertions of right are the strongest tools of the law." ${ }^{\text {"61 }}$ Rousseau and colleagues point to the growing legitimacy of the human 
rights framework, which by the mid-1990s was endorsed and utilized by a wide range of international actors. ${ }^{62}$

Dauvergne believes that in the case of asserting health rights claims on the behalf of refugee claimants, rights based advocacy is often practically ineffective, as it implies a controversial obligation and positive duty for host societies to provide health care to those who are not full members. ${ }^{63}$ It is true that while there is broad-based international support in Western countries for civil and political rights, there is ambivalence from these governments on social rights. ${ }^{64}$

An additional challenge with rights discourse in this context is that it may not be as familiar a mode of advocacy for health professionals. Both Castañeda and Willen report that health professionals concerned about health-care access for refugee claimants most commonly frame this in humanitarian terms. ${ }^{65}$ Vanthuyne and colleagues conducted a survey with Canadian health professionals where a majority of respondents who believed uninsured patients should receive health care articulated this in terms of moral worthiness or "deservingness," rather than framing uninsured individuals as "subjects of rights." ${ }^{6}$ A rights discourse is perhaps less intuitive and actually challenges the privileged position that clinicians occupy in society.

Centring advocacy on a "right to health" may also meet challenges from those who assert that there is a lack of concreteness to the concept itself or that consensus acknowl edging its full existence is missing. Ruger claims that one would be "hard pressed to find a more controversial or nebulous human right than the "right to health."'67 Ambiguity around health rights has been attributed to various issues, including what Daniels describes as a lack of a proper philosophical foundation, ${ }^{68}$ and also the fact that tax-based health systems like Canada's did not develop within a legal rights framework but as part of the modern welfare state. ${ }^{69}$ Sources of the right to health, however, are not lacking. Contemporary international law, which includes the International Covenant on Economic, Social and Cultural Rights, provides a robust defence of the right to health that is inclusive of refugee claimants. Importantly, the ICESCR specifies a legal obligation on states to "respect the right to health by, inter alia, refraining from denying or limiting equal access for all persons, including prisoners or detainees, minorities, asylum-seekers and illegal immigrants, to preventive, curative and palliative health services" as well as to abstain from "enforcing discriminatory practices as a State policy."7o Seventy states are signatories to the ICESCR, though fewer have ratified it.

Despite some aforementioned challenges, from an advocacy standpoint rights-based arguments have certain advantages. They can help to avoid the Othering of the victim frame, changing the emphasis on access to health care from charity to obligation and thereby providing a more consistent source of legitimacy to refugee claimants as users of healthcare services. Claimants would not have to rely to the same extent on the empathy or compassion of health professionals in order to gain needed care. Biased ideas and preconceptions regarding refugee claimants have been found to be fairly common among health-care professionals. ${ }^{71}$ Given the necessary limitations of compassion as a basis for protecting the health of this population, repositioning refugee claimants as rights-holders appears to be a promising avenue. Further, by emphasizing the rights of refugee claimants, the capriciousness of public sentiment would be less likely to lead to new refugee health-care cuts. Host society sympathy for the plight of refugee claimants may fluctuate, and with it today's victims may be transformed into tomorrow's threats. Grounding the discourse in a language of rights, a more difficult status to strip away than victimhood, would create some protection for refugee claimants from these inevitable changing tides of popular opinion.

Some limitations of this work should be noted. First, materials analyzed were retrieved in three large databases by using specific keywords and phrases in English only. Perspectives expressed in mainstream French Canadian media, for example, may have been missed if not translated and included in English sources. Second, structural features of these texts were not assessed. Third, this article focuses on only one aspect of advocacy/policy mobilization and, although recognizing that individuals, organizations, and movements can hold and be shaped by conflicting frames, the necessarily reductive approach of frame analysis may have resulted in the exclusion of some perspectives. Frame analysis is only one tool for analysis that intends to contribute toward advocacy. Further study could consider the political opportunities, mobilization, and resources for social movement organizing by refugees.

\section{Conclusions}

The victim frame chosen by CDRC appears to have had efficacy, but it may have unintended effects. This article has asserted that there is a need to keep a critical gaze on discursive framing strategies employed in advocacy, even when these strategies have proven successful. In particular, the achievement of short-term goals must be thoughtfully considered in parallel to longer-term aims of broader political and social change. The potential advantages for refugee advocates of leaving rights out of the discussion should be further studied in addition to further assessment of potential risks in the way refugees and refugee claimants have been portrayed as victims.

What does the relative under-utilization of rights-based arguments say about the status of refugee claimants in Canada, 
and more generally, in Western host societies? It sheds light on the position of refugees in host societies as fundamentally unequal. Moreover, it is suggestive of a current ceiling on state commitments to refugees, and also of limited supplies of host population sympathy to the cause of refugee claimant empowerment beyond what can be achieved through charity. There may be a generalized willingness to help and extend services, but only on certain terms. Help is rendered with a certain self-satisfaction and can be withheld on reasonably justifiable grounds because assistance is optional and beyond the bounds dictated by duty.

A more secure foundation for justifying refugee claimants' access to critically needed health services could be built around portraying them as rights-holders, rather than as deserving recipients of well-intentioned charity. In pragmatic terms, however, advocacy based on a victim frame may be the best solution to achieving immediate results to urgent problems such as gaps in health coverage. What is important from an advocacy standpoint is that discourses that are selected be critically evaluated for their weak points as well as benefits, the ways they are potentially hurting as well as helping. Refugee claimants are rarely afforded the opportunity to tell their own stories, and so the stories that are told about them have significant influence in defining their public image, setting the terms of the debate over their level of access to health services.

\section{Notes}

1 I would like to acknowledge those who provided feedback on earlier drafts, including Mónica Ruiz-Casares, Cécile Rousseau, Janet Cleveland, and Alicia Swords. Thanks is also owed to two anonymous reviewers for the clarity and precision they helped add to this piece.

2 Matthew Gibney, "Precarious Residents: Migration Control, Membership and the Rights of Non-Citizens" (research paper, United Nations Development Programme, Human Development Reports, 2009).

3 Matthew B. Stanbrook, "Canada Owes Refugees Adequate Health Coverage," CMAJ: Canadian Medical Association Journal 186, no. 2 (2014): 91.

4 Michael B. Katz, The Undeserving Poor: From the War on Poverty to the War on Welfare (New York: Pantheon Books, 1990).

5 See Roger Fowler, Bob Hodge, Gunther Kress, and Tony Trew, Language and Control (London: Routledge and Kegan Paul, 1979); Teun A. Van Dijk, "Principles of Critical Discourse Analysis," Discourse \& Society 4, no. 2 (1993): 249-83; Norman Fairclough, Discourse and Social Change (Cambridge: Polity, 1992).

6 See Charles J. Fillmore, "Frame Semantics and the Nature of Language," Annals of the New York Academy of Sciences 280, no. 1 (1976): 20-32; Erving Goffman, Frame
Analysis: An Essay on the Organization of Experience (Cambridge, ma: Harvard University Press, 1974).

7 Nelson Phillips and Cynthia Hardy, "Managing Multiple Identities: Discourse, Legitimacy and Resources in the UK Refugee System," Organization 4, no. 2 (1997): 159-85.

8 Liisa H. Malkki, "Speechless Emissaries: Refugees, Humanitarianism, and Dehistoricization," Cultural Anthropology 11, no. 3 (1996): 390.

9 George Lakoff, The All New Don't Think of an Elephant! Know Your Values and Frame the Debate (White River Junction, vт: Chelsea Green Publishing, 2014).

10 Goffman, Frame Analysis, 21.

11 Charles Fillmore, "Frame Semantics."

12 Neta Kligler-Vilenchik and Kjerstin Thorson, "Good Citizenship as a Frame Contest: Kony2012, Memes, and Critiques of the Networked Citizen," New Media \& Society 18, no. 9 (2015): 1993-2011.

13 William A. Gamson and Andre Modigliani, "Media Discourse and Public Opinion on Nuclear Power: A Constructionist Approach," American Journal of Sociology 95, no. 1 (1989): 1-37.

14 Pierre Bourdieu, Outline of a Theory of Practice (Cambridge: Cambridge University Press, 1977), 164.

15 George Lakoff, The Political Mind: A Cognitive Scientist's Guide to Your Brain and Its Politics (New York: Penguin, 2008).

16 Robert D. Benford and David A. Snow, "Framing Processes and Social Movements: An Overview and Assessment," Annual Review of Sociology (2000): 611-39.

17 Pamela Oliver and Hank Johnston, "What a Good Idea! Ideologies and Frames in Social Movement Research," Mobilization: An International Quarterly 5, no. 1 (2000): 37-54.

18 Benford and Snow, "Framing Processes and Social Movements," 613 .

19 Stuart Hall, "The Rediscovery of Ideology: Return of the Repressed in Media Studies," in Cultural Theory and Popular Vulture: A Reader, ed. John Storey (Essex: Pearson Education, 1982), 124-55.

20 Peter Teo, "Racism in the News: A Critical Discourse Analysis of News Reporting in Two Australian Newspapers," Discourse \& Society 11, no. 1 (2000): 7-49.

21 Harald Bauder, "Dialectics of Humanitarian Immigration and National Identity in Canadian Public Discourse," Refuge: Canada's Journal on Refugees 25, no. 1 (2008): 84-93.

22 Ibid.

23 See Victoria Esses, Stelian Medianu, and Andrea S. Lawson, "Uncertainty, Threat, and the Role of the Media in Promoting the Dehumanization of Immigrants and Refugees," Journal of Social Issues 69, no. 3 (2013): 518-36; Costas Gabrielatos and Paul Baker, "Fleeing, Sneaking, Flooding: A Corpus Analysis of Discursive Constructions of Refugees and Asylum-seekers in the UK Press, 1996-2005," Journal of English Linguistics 36, no. 1 (2008): 5-38; Natalie J. Grove and Anthony B. Zwi, "Our Health and Theirs: Forced 
Migration, Othering, and Public Health," Social Science \& Medicine 62, no. 8 (2006): 1931-42; Natascha Klocker, "Community Antagonism towards Asylum-seekers in Port Augusta, South Australia," Australian Geographical Studies 42, no. 1 (2004): 1-17.

24 "Reform of the Interim Federal Health Program Ensures Fairness, Protects Public Health and Safety," Citizenship and Immigration Canada, news release, 25 April 2012, http://news.gc.ca/web/article-en.do?nid=670949.

25 Allison Jones, "Doctors' Group Takes Ottawa to Court over Refugee Health-Care Cuts," Globe and Mail, 25 February 2013, http://www.theglobeandmail.com/ news/politics/doctors-group-takes-ottawa-to-court-over -refugee-health-care-cuts/article9047552/.

26 Aaron Wherry, "Bogus Refugee Claimants Receiving Gold-Plated Health Care Benefits," Maclean's, July 2012.

27 Donald Galloway, "Rights and the Re-identified Refugee: An Analysis of Recent Shifts in Canadian Law," in Refugee Protection and the Role of Law (Oxon, NY: Routledge, 2014), 53.

28 Rachel Tribe, "Mental Health of Refugees and AsylumSeekers," Advances in Psychiatric Treatment 8, no. 4 (2002): 244.

29 Stelian Medianu, Alina Sutter, and Victoria Esses, "The Portrayal of Refugees in Canadian Newspapers: The Impact of the Arrival of Tamil Refugees by Sea in 2010," IdeAs 6 (2015), http://ideas.revues.org/1199; Sailaja Krishnamurti, "Queue-Jumpers, Terrorists, Breeders: Representations of Tamil Migrants in Canadian Popular Media," South Asian Diaspora 5, no. 1 (2013): 139-57.

30 Jeffrey Reitz, "Economic Opportunity, Multiculturalism, and the Roots of Popular Support for High Immigration in Canada," in Anti-Immigrant Sentiments, Actions and Policies: The North American Region and the European Union, ed. Mónica Verea, 291-310 (Coyoacán: Center for Research on North America, 2012).

31 Kelly Hobson, "More Than $70 \%$ of Canadians Think Liberals' New Refugee Target Is Too High: Poll," National Post, 19 February 2016.

32 Nicholas Keung, "Canada's Refugee Acceptance Rate up Despite Asylum Restrictions," Toronto Star, 1 March 2015, http://www.thestar.com/news/immigration/2015/03/o1/ canadas-refugee-acceptance-rate-up-despite-asylumrestrictions.html.

33 Oscar Vigil, "Canadian Association of Refugee Lawyers: Response to Bill C-31," Revista Debate, 16 February 2012, http://www.revistadebate.net/revista_debate_wp/? $p=2525$.

34 Cathy Gulli, "Harper Says Only Bogus Refugees Are Denied Health Care. He's wrong," Maclean's, 25 September 2015, http://www.macleans.ca/politics/harper-says-only-bogus -refugees-are-denied-health-care-hes-wrong/.

35 Janet Cleveland, email message to author, 21 December 2015.

36 See Canadian Doctors for Refugee Care v Canada (Attorney General), 2014 FC 651, at para 11, Mactavish A.; Debra
Black, “Court Strikes Down Conservatives' Cuts to Refugee Health-Care Coverage," Toronto Star, 4 July 2014, http://www.thestar.com/news/canada/2014/o7/o4/court _rules_against_conservative_governments_refugee_ health_cuts.html.

37 Gulli, "Harper Says Only Bogus Refugees Are Denied Health Care."

38 Nehanda, "In Canada, More Vulnerable Refugees Being Denied Access to Health Care," Canadian Progressive, 24 October 2012, http://www.canadianprogressiveworld. com/2012/10/24/in-canada-more-vulnerable-refugeesbeing-denied-access-to-health-care/.

39 Danyaal Raza, Meb Rashid, Lynda Redwood-Campbell, Katherine Rouleau, and Phillip Berger, "A Moral Duty: Why Canada's Cuts to Refugee Health Must Be Reversed," Canadian Family Physician 58, no. 7 (2012): 729.

40 Ibid., 728.

41 Ibid.

42 Christopher Holcroft, "Tired of Bogus Tirades, Canadian Doctors for Refugee Care Challenge Minister of Citizenship and Immigration to a Public Debate," Canadian Doctors for Refugee Care, 27 January 2014, http://www .doctorsforrefugeecare.ca/.

43 Baldwin Van Gorp, "Where Is the Frame? Victims and Intruders in the Belgian Press Coverage of the Asylum Issue," European Journal of Communication 20, no. 4 (2005): 484-507.

44 Ibid.

45 Rosemary Sales, "The Deserving and the Undeserving? Refugees, Asylum-seekers and Welfare in Britain," Critical Social Policy 22, no. 3 (2002): 456-78.

46 Fuyaki Kurasawa, "How Does Humanitarian Visuality Work? A Conceptual Toolkit for a Sociology of Iconic Suffering," Sociologica 9, no. 1 (2015): 2.

47 Nora Gottlieb, Dani Filc, and Nadav Davidovitch, "Medical Humanitarianism, Human Rights and Political Advocacy: The Case of the Israeli Open Clinic," Social Science \& Medicine 74, no. 6 (2012): 839-45.

48 Jan Van Dijk, "Free the Victim: A Critique of the Western Conception of Victimhood," International Review of Victimology 16, no. 1 (2009): 1-33.

49 Morton Beiser, Strangers at the Gate: The "Boat People's" First Ten Years in Canada (Toronto: University of Toronto Press, 1999).

50 Cynthia Hardy and Nelson Phillips, "No Joking Matter: Discursive Struggle in the Canadian Refugee System," Organization Studies 20, no. 1 (1999): 8.

51 Edward Said, Orientalism (New York: Vintage, 1994).

52 Heather L. Johnson, "Click to Donate: Visual Images, Constructing Victims and Imagining the Female Refugee," Third World Quarterly 32, no. 6 (2011): 1015-37.

53 Prem Kumar Rajaram, "Humanitarianism and Representations of the Refugee," Journal of Refugee Studies 15, no. 3 (2002): 251. 
54 Miriam Ticktin, "Where Ethics and Politics Meet: The Violence of Humanitarianism in France," American Ethnologist 33, no. 1 (2006): 45.

55 Sarah S. Willen, "How Is Health-related 'Deservingness' Reckoned? Perspectives from Unauthorized Im/migrants in Tel Aviv," Social Science \& Medicine 74, no. 6 (2012): 812.

56 Hugo Slim., "Dissolving the Difference between Humanitarianism and Development: The Mixing of a Rights-Based Solution." Development in Practice 10, nos. 3-4 (2000): 291.

57 Catherine Dauvergne, "The Dilemma of Rights Discourses for Refugees," University of New South Wales Law Journal 23 (2000): 56-7.

58 Mark Heywood. "South Africa's Treatment Action Campaign: Combining Law and Social Mobilization to Realize the Right to Health," Journal of Human Rights Practice 1, no. 1 (2009): 14-36.

59 Cleveland, e-mail message.

60 Savitri Taylor, "Importance of Human Rights Talk in Asylum-seeker Advocacy: A Response to Catherine Dauvergne," University of New South Wales Law Journal 24, no. 1 (2001): 191.

61 Dauvergne, "Dilemma of Rights Discourses for Refugees," 56.

62 See Cécile Rousseau, Sonia Ter Kuile, Marie Muňoz, Lucie Nadeau, Marie-Jo Ouimet, Laurence Kirmayer, and François Crépeau, "Health Care Access for Refugees and Immigrants with Precarious Status: Public Health and Human Right Challenges," Canadian Journal of Public Health 99, no. 4 (2008): 290-2.

63 Ibid.

64 Henry J. Steiner, Philip Alston, and Ryan Goodman, International Human Rights in Context: Law, Politics, Morals: Text and Materials (New York: Oxford University Press, 2008), 281

65 See Heide Castañeda, "Medical Humanitarianism and Physicians' Organized Efforts to Provide Aid to
Unauthorized Migrants in Germany," Human organization 70, no. 1 (2011): 1-10; Sarah S. Willen, "Do 'Illegal' Im/migrants Have a Right to Health? Engaging Ethical Theory as Social Practice at a Tel Aviv Open Clinic," Medical Anthropology Quarterly 25 no. 3 (2011): 303-30.

66 Karine Vanthuyne, Francesca Meloni, Monica Ruiz-Casares, Cécile Rousseau, and Alexandra Ricard-Guay, "Health Workers' Perceptions of Access to Care for Children and Pregnant Women with Precarious Immigration Status: Health as a Right or a Privilege?," Social Science \& Medicine 93 (2013): 78-85.

67 Jennifer Prah Ruger, "Toward a Theory of a Right to Health: Capability and Incompletely Theorized Agreements," Yale Journal of Law \& the Humanities 18, no. 2 (2006): 1.

68 Norman Daniels, Just Health Care (New York: Cambridge University Press, 1985).

69 Colleen Flood and Aeyal Gross, "Litigating the Right to Health: What Can We Learn from a Comparative Law and Health Care Systems Approach?" Health and Human Rights 16, no. 2 (2014): 62-72.

70 UN General Assembly, General Comment no. 14, "The Right to the Highest Attainable Standard of Health," 11 August 200o, http://apps.who.int/disasters/repo/13849_ files/o/Un_human_rights.htm.

71 Marita Eastmond, "Nationalist Discourses and the Construction of Difference: Bosnian Muslim Refugees in Sweden," Journal of Refugee Studies 11, no. 2 (1998): 161-81.

Jesse Beatson is a first-year law student at Osgoode Hall Law School. The author may be contacted at jessechisholmbeatson2016@osgoode.yorku.ca.

(C) Jesse Beatson, 2016. This open-access work is licensed under a Creative Commons Attribution-NonCommercial 4.0 International License, which permits use, reproduction and distribution in any medium for non-commercial purposes, provided the original author(s) are credited and the original publication in Refuge: Canada's Journal on Refugees is cited. 